\title{
ESTADO, POLÍTICA E EMANCIPAÇÃO HUMANA EM MARX
}

\author{
STATE, POLITICS AND EMANCIPATION OF MANKIND IN MARX
}

\author{
Antonio Valricélio Linhares da Silva ${ }^{1}$ \\ Enéas Arrais Neto ${ }^{2}$ \\ Epitácio Macário ${ }^{3}$
}

\section{RESUMO}

Neste breve ensaio faremos uma incursão sobre dois importantes escritos de Marx, Sobre a questão judaica (MARX, 2010) e Glosas críticas marginais ao artigo "O rei da Prússia e a Reforma Social". De um Prussiano (1995). Fazendo uma síntese destes escritos, abordaremos a relação entre a natureza do Estado e da política, seus limites e a questão da emancipação humana. Assim, compreender a emancipação humana, isto é, a efetivação da liberdade real do homem, sua afirmação existencial concreta enquanto ser genérico, um ser que cria a cultura e a si mesmo conscientemente, portanto livre da alienação, é um desafio atual, não só porquesua antítese permanece, mas também porque ainda é mal entendida quanto às origens de sua negação e a forma de superação radical dos males que se sobrepõem a ela. Consideramos, portanto, a partir da leitura das referidas obras, em particular quanto à relação entre a natureza do Estado e da política, em contraponto a emancipação humana, que Marx não apresenta como alternativa ao Estado burguês, por exemplo, outro tipo de Estado ou um Estado sob outra direção, mas afirma a necessidade da superação do próprio Estado moderno, tendo em vista o fato de este corresponder à própria negação da universalidade real do homem.

Palavras-chave: Estado - Política - Emancipação humana

\begin{abstract}
In this brief assay we will make an incursion over two important writings of Marx, On the Jewish Question (MARX, 2010) and Critical Notes on the Article "The King of Prussia and Social Reform. By a Prussian (1995). Making a synthesis of these writings, we will approach relation among State and politics nature, its limits and the issue of emancipation of mankind. Thus, comprehending emancipation of mankind, namely, effectivation of real freedom of mankind, its concrete, existential affirmation while generic being, an one that creates culture and himself consciously, so free of alienation, is a current challenge, not just because its antithesis remains, but also because it's misunderstood yet regarding its negation's origins and the way of radical overcoming evils that overlap it. We consider, so, from the reading of referred works, particularly to relation among State and politics nature, in counterpoint to human emancipation, that Marx doesn't present like alternative to bourgeois State, for example, another kind of State or an one under other direction, but claims the need of overcoming by modern State itself, due to the fact that this corresponding to own negation of real man's universality.
\end{abstract}

Keywords: State - Politics - Emancipation of Mankind 


\section{D’A QUESTÃO JUDAICA: O ESTADO POLÍTICO E A QUESTÃO DA EMANCIPAÇÃO RELIGIOSA E POLÍTICA.}

Bruno Bauer achava-se diante de uma questão para ele fundamental, a busca da emancipação perseguida pelos judeus alemães. Mas em sua pátria encontrava-se diante da necessidade da emancipação política e, por conseguinte, da emancipação humana. Assim, sugeria aos judeus que estes deviam, na condição de alemães, "trabalhar pela emancipação política da Alemanha" e, enquanto homens, "pela emancipação da humanidade" (MARX, 2010, p. 33).

Trata da questão judaica explorando a natureza do judeu, fazendo a crítica da religião judaica, analisando a oposição religiosa entre judaísmo e cristianismo e por fim, explicando a essência do Estado cristão. Para elea emancipação do judeu não seria possível sem a emancipação de todos, sem abolir a religião, sem abolir o Estado religioso cristão. "Ao querer a emancipação do Estado cristão, o judeu pede que o Estado cristão renuncie ao seu preconceito religioso [...]" (idem). Mas, pela natureza de ambos, nem o Estado cristão nem os judeus podem ser emancipados. Bauer sustentava que "o Estado cristão, por sua própria essência, não pode ser emancipado, mas[...], o judeu, por sua própria essência não pode ser emancipado. Enquanto o Estado for cristão e o judeu judaico, ambos serão igualmente incapazes tanto de conceder quanto de receber a emancipação" (Ibid, p. 34). Contudo, de acordo com Marx, Bauer resolve a questão judaica nos próprios limites da questão, de modo que na formulação do problema encontra-se a sua própria resolução. Assim, a crítica à questão judaica é a crítica à emancipação requerida pelos judeus e a crítica ao Estado cristão.

Qual seria a imediata situação do judeu alemão, seu sofrimento existencial? Bauer responderia, como está descrito em Marx: a carência de emancipação política e o acentuado cristianismo do Estado. Em síntese, como Marx apresenta, a questão judaica para Bauer tem significado geral, a despeito da especificidade da Alemanha, é um problema unicamente da relação entre religião e Estado, entre preconceito religioso, [segregação religiosa e humana pela religião] e a emancipação política. De modo que a emancipação da religião põe-se como condição tanto ao judeu como ao Estado, sendo que este deveria emancipar o judeu e emancipar-se a si próprio. 
Assim, a condição da emancipação do judeu é que ele abandone sua religião, do mesmo modo que a condição da emancipação do Estado é que ele deixe de ser cristão, no caso do Estado alemão, ou de maneira geral, que passe a ser laico - o que praticamente equivale a transferir a religião para a esferada sociedade civil, constituindo-se um Estadoaperfeiçoado, ateu, democrático, aquele que garante a liberdade e a igualdade.

Contudo, Marx demonstra empiricamente que tais Estados, embora não fossem devidamente considerados na análise de Bauer, já existiam da mesma forma que na democracia norte-americana, sem uma religião oficial, mas com a presença massiva da religião no seio da sociedade civil.

Ora, esta constatação de Marx é logo seguida de uma inabalável conclusão: a abolição da religião por parte do Estado não faz desaparecer a religião nem garante a emancipação, a liberdade do homem diante da alienação religiosa.Em relação a este último caso, os Estados emancipados da religião postulam a igualdade e a liberdade, mas tão somente no plano formal,mantendo a particularidade das esferas da vida social na forma da propriedade privada, ou como atesta Marx de maneira mais substancial:

O Estado anula à sua maneira a diferenciação por nascimento, estamento, formação e atividade laboral ao declarar, nascimento, estamento, formação e atividade laboral como diferenças apolíticas, ao proclamar cada membro do povo, sem consideração dessas diferenças, como participante voluntário da soberania nacional, ao tratar todos os elementos da vida real de um povo a partir do ponto de vista do Estado. Não obstante, o Estado permite que a propriedade privada, a formação, a atividade laboral atuem à maneira delas, isto é, como propriedade privada, como formação, como atividade laboral e tornem efetiva a sua essência particular(MARX, p. 39-40).

E a maneira de ser do Estado não é uma mera contingência acidental, mas um modus operandi necessariamente liberal, daí que a forma particular de atuação destas instituições sociais (propriedade privada, formação, trabalho) encontre na atuação do Estado a sua forma particular de ser, a forma da propriedade privada.

Marx considera que Bauer não só cai em contradições, mas lança questões que não pode responder por não questionar nem o tipo de emancipação nem o tipo de Estado. O engano de Bauer é visível 
[...] no fato de só submeter à crítica tão somente o "Estado cristão", mas não o "Estado como tal", no fato de não investigar a relação entreemancipação política e emancipaçãohumana e, em consequência, de impor condições que só se explica a partir da confusão acrítica da emancipação política com a emancipação humana geral (Ibid, p. 36).

Para Marx, conforme o Estado onde o judeu se encontre, a crítica de Bauer recebe formulação diferente: na medida em que a crítica de Bauer se limita a um Estado onde não se configure como político, não emancipado da religião, como na Alemanha, a questão judaica é puramente teológica, de maneira que a crítica é, neste caso, a crítica bivalente da teologia (cristã e judaica). A crítica deixa de ser teológica quando o Estado onde se encontra o judeu é um Estado laico, emancipado da religião, passando a ser crítica do Estado político. Mas para Marx, é neste ponto,no qual a crítica deixa de ser teológica, que a crítica de Bauer deixa de ser crítica para cair no equívoco de não considerar a natureza do Estado e da própria emancipação política e humana.

Resta-nos agora somente mais uma importante observação nesta incursão sobre a questão judaica: no Estado aperfeiçoado, democrático, ateu, o homem - embora não reconhecido por Bauer - surge na sociedade civil como um fenômeno ilusório, ao passo que no Estado (na sociedade política), onde é visto como um ser genérico [de Feuerbach] o homem é o membro imaginário de uma soberania ilusória, despojado de sua vida real individual, e dotado de uma universalidade igualmente irreal.

Para evitar que seja tomado como quem rejeita a emancipação política, o próprio Marx esclarece que "A emancipação políticade fato representa um grande progresso;não chega a ser a forma definitiva da emancipação humana em geral, mas constitui a forma definitiva da emancipação humana dentro da ordem mundial vigente até aqui. Que fique claro: estamos falando aqui de emancipação real, de emancipação prática" (Ibid, p. 41).“Todavia”, continua adiante, "não tenhamos ilusões quanto ao limite da emancipação política [...]” (Ibid, p. 42).

Depreende-se aqui en passant que a emancipação política do homem não se realiza na emancipação política do Estado. Mesmo tendo este se libertado da religião e se constituído, como queria Bauer, em Estado político, mantém o princípio da liberdade e da igualdade apenas como postulações universais abstratas, supera 
formalmente a propriedade privada, mas a mantém na medida em que a pressupõe e configura à sua forma (liberal burguesa) tanto o direito à propriedade, como o direito à educação, à profissionalização e, poderíamos dizer, à saúde e à moradia, tal como a garantia real de alimentação e uma renda mínima para superar a miséria, uma forma particular inerente ao próprio Estado democrático burguês de manter as contradições materiais das quais derivam aqueles elementos universais e as políticas de assistência social. De modo que na sociedade contemporânea, a resolução do problema da emancipação é adiada. Tanto em Bauer como para muitos políticos mesmo da esquerda do nosso tempo, a emancipação política não é reconhecida como parcial e limitada.

Neste caso expresso em Sobre a questão judaica, o Estado, mesmo emancipado da religião, não pode conferir ao homem a emancipação política, muito menos a emancipação humana, uma vez que mantém-se preso necessariamente a uma outra condição, a de ser uma instância do poder burguês, para o qual a liberdade e a verdadeira emancipação humana encontra seu limite na propriedade privada e na reprodução material do modo social burguês.Por mais diferentes que sejam os Estados dos diferentes países civilizados, "em que pese à confusa diversidade de suas formas, têm de comum o fato de que todos eles repousam sobre as bases da moderna sociedade burguesa, ainda que em alguns lugares esta se ache mais desenvolvida do que em outros, no sentido capitalista".

\section{DAS GLOSAS CRÍTICAS MARGINAIS AO ARTIGO "O REI DA PRÚSSIA E A REFORMA SOCIAL". DE UM PRUSSIANO. O ESTADO, A ALMA POLÍTICA E O DESAFIO DE SUPERAR O PAUPERISMO.}

É em mais uma polêmica com um de seus contemporâneos que Marx oferece ao mundo uma teorização pertinente acerca da aparência eda essência do Estado e da política modernos e, vale dizer, hodiernos. Marx se dispõe a rasgar o tecido de erros escondidos em uma coluna de jornal, para os quais nem todos os leitores, segundo ele mesmo, poderiam ter cultura e o tempo necessário para perceber uma tal charlatanice literária. A charlatanice surge da cabeça de Arnold Ruge, que publica um artigo no Jornal Avante (Vorwärts), numa Alemanha cujo 
Estado ainda não atingira a forma moderna de um Estado político, livre da arte política religiosa cristã, ou, como Bauer queria, um Estado emancipado da religião.

Arnold Ruge, o prussiano, levanta a tese central de que

Num país não-político como a Alemanha [...] é impossível compreender que a miséria parcial dos distritos industriais é uma questão geral e menos ainda que é um dano para o conjunto da sociedade. Para os alemães, o acontecimento tem o mesmo caráter de qualquer seca ou carestia local. Por isso, o rei o considera como um "defeito de administração e de assistência" (MARX, 1995, p. 4.)

De fato, para Ruge, é no caráter não-político da Alemanha que se encontra a origem da miséria, ou do pauperismo local, de onde surge a conclusão do rei prussiano de que esta causa está na falha da administração e da assistência. Os meios contra o pauperismo estariam numa atitude política de um Estado político, isto é, o enfrentamento do problema seria possível com ações institucionais de ordem administrativa, por medidas legais e assistenciais. O que equivaleria a resolver as falhas de administração, típicas de um Estado não desenvolvido.

Ruge chegava a estas conclusões equivocadas a despeito das muitas investidas políticas de outros Estados contra o crescimento do pauperismo ou miséria (termo mais conhecido no Brasil), como era o caso do Estado inglês e do francês que, embora sendo nações desenvolvidas politicamente, não conseguiram reconhecer a origem real do pauperismo de operários ou o avanço da mendicância, muito menos conseguiram resolvê-los de modo definitivo, a não ser penalizando as vítimas imediatas do estado de miséria a que estavam lançados.

De acordo com Marx, no caso do tratamento dado pelo Estado inglês ao pauperismo, sua origem estaria, num primeiro momento, na falha da assistência, ou na carência de assistência eficaz contra a miséria e, num segundo momento, após muitas investidas assistenciais típicas de um Estado político moderno, no excesso de assistência, restando a explicação maulthusiana de que o pauperismo é resultante deuma eterna lei natural, inerente aos pobres, culpa deles e neles punida. No caso do Estado francês, também desenvolvido politicamente em relação à Alemanha, o pauperismo é enfrentado por Napoleão à forma de um golpe: uma lei de repressão à mendicância, que instituía depósitos de mendigos, verdadeiras penitenciárias (Cf. MARX, 1995). 
A conclusão imediata a que Marx chega, embora não seja agora novidade, é a de que, "[...] por mais que os Estados tivessem se ocupado do pauperismo, sempre se ativeram a medidas de administração e de assistência, ou, ainda mais, desceram abaixo da administração e da assistência" (Ibid, p. 9). Ainda hoje os administradores dos Estados perseguem uma fórmula de combate à miséria por meio de medidas administrativas e assistenciais, seja por sua formação partidária liberal burguesa, seja por cegueira teórica ou até mesmo por cinismo. E não adianta apelar para a criatividade quando esta se encontra limitada às determinações do Estado e da política. Embora reconheçamos que aquele que tem sede precisa beber e aquele que tem fome precisa comer e que as políticas assistenciais têm seu papel considerável.

Estas incursões sobre os limites da percepção ingênua de Ruge já bastam para expormos agora as assertivas centrais apresentadas por Marx. A primeira é a de que o Estado jamais encontrará nele mesmo e na organização da sociedade o fundamento dos males sociais; o Estado e a organização da sociedade não são, em termos políticos, duas coisas diferentes, acrescenta Marx; todos os Estados procuram as causas em diferenças acidentais intencionais da administração, indicando como remédio aos males as medidas administrativas; o Estado não pode eliminar a contradição entre a função e a boa vontade da administração e seus meios e possibilidades sem eliminar a si mesmo, pois repousa sobre esta contradição; o Estado repousa sobre outra contradição, a contradição entre sua universalidade e a vida privada (o interesse burguês), de maneira que se o Estado quisesse acabar com a impotência de sua administração, teria que acabar com a atual vida privada, conclui Marx.

Mais uma citação direta das Glosas críticas não poderia escapar aqui:

Quanto mais poderoso é o Estado e, portanto, quanto mais político é um país, tanto menos está disposto a procurar no princípio do Estado, portanto, no atual ordenamento da sociedade, do qual o Estado é a expressão ativa, autoconsciente e oficial, [tanto menos está disposto a procurar] os fundamentos dos males e a compreender-Ihes o princípio geral. O intelecto político é político exatamente na medida em que pensa dentro dos limites da política [...] (Ibid, p. 11).

Poderíamos pensar insistentemente, à contra-senso, que um maior desenvolvimento da consciência política, ou da política mesmo, elevaria a 
capacidade de percepção da origem das incontingências sociais, como pretenderiam os políticos profissionais ou os que se atêm ao exclusivismo da política como instância de poder de ordem suprema. Mas para seu desgosto, Marx sugere mais uma estonteante argumentação certeira quanto à natureza unilateral do pensamento político: "[...] quanto mais perfeito é o intelecto político, tanto mais ele crê na onipotência da vontade e tanto mais é cego frente aos limites naturais e espirituais da vontade e, consequentemente, tanto mais é incapaz de descobrir a fonte dos males sociais [...]" (Ibid, p. 12).

Sendo assim, nos perguntaríamos ainda: Marx nega a política? Esta deve ser abandonada como estratégia pelo movimento revolucionário? Na verdade, temos em Marx uma negação dialética da política para demonstrar com evidência seus limites. Dadaa sua natureza, isto é, o fato de ser um reflexo do tipo de sociedade dividida em classes antagônicas, a política não pode ultrapassar seu limite, a linha divisória entre ser o espírito do Estado, pautado pelo interesse particular (de salvaguardar a propriedade privada, a propriedade burguesa) e ser um ponto de vista unilateral, dicotomizado da totalidade social.

Marx concorda com o prussiano, quando este afirma que "uma revolução social sem alma política (isto é, sem uma visão organizativa do ponto de vista da totalidade) é impossível" (RUG, apud MARX, 1995, p. 18). Concorda na medida em que esta totalidade envolva o conjunto das contradições sociais, desde a materialidade às instâncias simbólicas subsequentes. Isso porque para Marx, uma revolução social situa-se do ponto de vista da totalidade e não da parcialidade absolutizada da alma política. A revolução social assume uma dimensão de totalidade na medida em que é um protesto do homem contra a vida desumanizada. O seu ponto de vista não é o de uma totalidade abstrata daquele Estado cuja subsistência se faz na separação da vida real do homem, mas de uma totalidade concreta na qual se faz a vida real do homem.

Confirmando a afirmação da política no sentido dialético em Marx, ele mesmo considera que "toda revolução dissolve a velha sociedade; neste sentido é social. Toda revolução derruba o velho poder; neste sentido é política" (MARX, 1995, p. 18). A política é, assim, articulada com a revolução social que, ao reestruturar a sociedade de cima abaixo, supera as bases da própria política e do Estado. A política articulada à revolução social tende a negar-se a si mesma. A este respeito 
Marx conclui que "logo que tenha início a sua atividade organizativa, logo que apareça o seu próprio objetivo, a sua alma, então o socialismo se desembaraça do seu revestimento político".

Concluímos que, para um movimento revolucionário, sua meta central não pode ser o polimento da política, que é, antes de tudo, o fortalecimento do Estado. Não foi isso mesmo o que ocorreu com a experiência fracassada do socialismo real? O Estado não só foi fortalecido, como foi o instrumento de negação do próprio socialismo. Não por acaso, a alma política da revolução, ou a política com toda a sua limitação óptica e pragmática, estava incorporada na figura do partido. Alma política que criou um círculo dirigente ativo e cegamente apoiado na natureza limitada do Estado e da política.

Mészáros (2009) tem alertado, ao apontar os erros da revolução socialista, que o Estado, um dos elementos do tripé de sustentação do capital, manteve-se intacto. Por isso mesmo é que a ação revolucionária foi logo sufocada pelos limites da ação política que pairava sobre os círculos dirigentes que viviam às custas da própria sociedade que dirigia. Por isso mesmo é que o capital se reproduzia e controlava os destinos da vida social, presa por sua vez aos limites do trabalho assalariado.

\section{CONSIDERAÇÕES FINAIS}

Se depender do Estado, mesmo o Estado político de Bauer, ou da alma política do Estado de Ruge, a emancipação humana não será atingida. O Estado não pode conceder emancipação política e religiosa, muito menos a emancipação humana, pois não é possível a ele libertar-se de sua própria limitação, de sua universalidade formal, ou essência burguesa.

A questão atual, como no tempo de Marx, não é a da emancipação religiosa, ou política, embora esta seja importante, ou mesmo a de saber qual Estado é ou não capaz de garantir a emancipação humana: o não-político, o político laico, liberal, ou o político socialista. Marx não colocava como alternativa ao Estado burguês, por exemplo, um outro tipo de Estado, sob outra direção, mas afirmava a necessidade da superação do próprio Estado moderno, tendo em vista o fato de este corresponder à própria negação da universalidade real do homem. 
Também a questão não é saber se uma forma ou outra de ação política do Estado, se de administração ou de assistência, pode superar a miséria, muito menos se um partido ou outro é o mais eficiente neste intento social. Aliás, a generosidade do Estado ou de um partido quando implementam um programa de assistência só pode se afirmar, ou se nutrir na existência do objeto de sua falsa generosidade, a miséria, a pobreza, ou numa outra gradação social após um suposto êxito em superar a miséria e a pobreza, no baixo poder de consumo das massas.

O Estado e a política não podem garantir a emancipação humana. $O$ primeiro sujeito" jamais encontrará em si e na sociedade o fundamento dos males sociais, já que ele é a fonte desses males sociais" (CHAGAS, 2007). Neste caso, como pode um sujeito negar conscientemente a si mesmo quando sua tendência inevitável é sua auto-reprodução? A política não tem outra forma de ser senão segundo o interesse do Estado, agirconforme as projeções da sociabilidade que sustenta e é grandemente sustentada pelo Estado, sociabilidade que só pode ser negada historicamente por uma revolução social que garanta a emancipação real do homem. 


\section{REFERÊNCIAS}

CHAGAS, Eduardo Ferreira. A crítica à política em Marx. In SOUSA, Adiana e Silva; OLIVEIRA, Elenilce Gomes de; et. al.: (orgs). Trabalho, filosofia e educação no espectro da modernidade tardia. Fortaleza: Edições UFC, 2007. (p.67-81).

MARX, Karl. Glosas críticas marginais ao artigo "O rei da Prússia e a Reforma Social". De um Prussiano. Revista Práxis. n. 5. Tradução de Ivo Tonet. Belo Horizonte, 1995. Disponível em: <http://www.marxists.org/portugues/marx/1844/08/07.htm>.

. Observações à margem do programa do partido operário alemão. In MARX, Karl; ENGELS, Friedrich. Obras escolhidas. Volume 2. São Paulo: Alfa-Omega, s/d. . Sobre a questão judaica. Tradução de Nélio Schneider. São Paulo: Boitempo, 2010.

MÉSZÁROS, Istiván. Para além do capital: rumo a uma teoria da transição. 3. reimpressão. São Paulo: Boitempo, 2009.

\footnotetext{
${ }^{1}$ Aluno do Mestrado em Educação Brasileira da UFC. E-mail: valricelio2@yahoo.com.br

${ }^{2}$ Doutor em Educação Brasileira pela UFC. E-mail: eneas_arrais@hotmail.com

${ }^{3}$ Doutor em Educação Brasileira pela UFC. E-mail: e_macarius@yahoo.com.br

${ }^{4}$ Cf. MARX, Karl. Observação à margem do programa do partido operário alemão. In MARX, K. e ENGELS, F.Obras escolhidas. V.2 São Paulo: Editora Alfa-Omega, s/d, p. 221.

ENVIADO EM: 30.06.2012

APROVADO EM: 11.07.2012
} 